\title{
Detection of antigonococcal IgA in cervical secretions by indirect immunofluorescence: an evaluation as a diagnostic test
}

\author{
A McMillan, ${ }^{\dagger}$ G MCNEILlage, + H YOUNG, $\neq$ AND S S R BAIN† \\ From the *Department of Sexually Transmitted Diseases, Black Street, Glasgow, and the +Departments \\ of Venereology and $¥$ Bacteriology, University of Edinburgh, Edinburgh
}

SUMMARY Using an indirect immunofluorescent-antibody method, antigonococcal $\operatorname{IgA}$ was detected in the cervical secretions of $56(72 \%)$ of 78 women with untreated gonorrhoea but in only $25(5 \%)$ of 490 non-infected women. The low sensitivity-comparable to that of Gram-stain microscopy - the expense, and the laboriousness of the test militate against its use as a routine diagnostic procedure.

\section{Introduction}

Although gonococcal antibodies in the serum of patients with gonorrhoea may be demonstrated by various methods, ${ }^{1}$ the detection of these antibodies has not proved useful as a diagnostic test. ${ }^{2} \mathrm{~A}$ serum antibody response may not be apparent until infection has been established for several days, and thus early gonorrhoea may be missed. ${ }^{2}$ Serum antibodies, particularly of the IgG class, remain detectable for weeks or months after successful treatment; ${ }^{3}$ interpretation of tests based on the demonstration of IgG antibody is therefore difficult. Wilkinson, ${ }^{4}$ using a fluorescent-antibody test, demonstrated significantly high titres $(\geqslant 16)$ of IgM antibody in only $24(43 \%)$ of 55 women with untreated gonorrhoea; Ison and Glynn $^{5}$ observed that the detection of IgM antibodies by an enzyme-linked immunosorbent assay was of little diagnostic help.

Gonorrhoea is essentially an infection of mucosal surfaces, and gonococcal antibodies may be demonstrated in the urethral and cervical secretions from infected men and women respectively. ${ }^{67}$ The local IgA antibody response antedates that of the serum, and in most cases antigonococcal IgA in the secretions cannot be detected two to three weeks after successful treatment. ${ }^{7}$

By microscopical examination of Gram-stained smears of material from the cervix and urethra, only about $55 \%$ of women with gonorrhoea will be

Address for reprints: Dr A McMillan, Department of Sexually Transmitted Diseases, Black Street, Glasgow G4

Received for publication 28 September 1979 identified. ${ }^{8}$ Culture on selective medium is the most sensitive procedure available for the diagnosis of gonorrhoea in women; however, results are not generally available until $\mathbf{4 8}$ hours after the collection of specimens. To control gonococcal infection within a community, a rapid and sensitive method of identifying infected, but asymptomatic, individuals is required. The purpose of this study was to determine if the detection of antibodies in cervical secretions could be used as a diagnostic test for gonorrhoea. Preliminary data are presented in this paper.

\section{Patients and methods}

STUDY POPULATION AND DIAGNOSIS

With the exception of pregnant women, all female patients who attended the Department of Sexually Transmitted Diseases, Black Street, Glasgow, and clinics held by one of us (SSRB) at the Department of Venereology, Royal Infirmary, Edinburgh, during a six-month period were studied.

The methods used in both centres for the diagnosis of gonorrhoea have previously been described.?

Patients were divided into three groups: (a) 78 women with untreated gonorrhoea; (b) 178 women who had previously been treated for gonorrhoea; and (c) 490 women who had no microbiological evidence of current gonococcal infection or a past history of gonorrhoea.

COLLECTION OF SPECIMENS

Under direct vision, a cottonwool-tipped applicator stick was inserted into the cervical canal to a distance 
of about $1 \mathrm{~cm}$ and allowed to remain in contact with the secretions for about 15 seconds. Secretions were eluted from the swab by placing this in $0.5 \mathrm{ml}$ of phosphate-buffered saline, $\mathrm{pH} 7 \cdot 4$, containing Tween $20(0.05 \% \mathrm{v} / \mathrm{v})$. Samples were frozen at $-20^{\circ} \mathrm{C}$ until required. After thawing and centrifugation at $2000 \times g$ for 15 minutes, the supernate was used for estimating $\operatorname{IgA}$ and $\operatorname{IgG}$ concentrations and for the indirect immunofluorescent-antibody test.

ESTIMATION OF IgA AND IgG CONCENTRATIONS Using commercially available, low-level immunodiffusion plates (Hoescht Pharmaceuticals, Hounslow, Middlesex) the concentrations of $\operatorname{IgA}$ and IgG in the supernate of diluted secretions from 18 patients selected at random were determined. Commercially available serum IgG (Travenol Laboratories, Norfolk) was used as reference standard; colostral IgA standard ${ }^{9}$ was used in the estimation of secretory $\operatorname{IgA}$.

\section{INDIRECT IMMUNOFLUORESCENT-ANTIBODY TEST}

The procedure has been described in detail elsewhere. ${ }^{3}$ Strain 9 of Neisseria gonorrhoeae, as described by $O$ 'Reilly and co-workers, ${ }^{10}$ was used as antigen. The grading of fluorescence was as follows: $4+$, brilliant fluorescence of all organisms; $3+$, well defined fluorescence of all organisms in the field; $2+$, low density fluorescence of at least $75 \%$ of organisms; and $1+$, occasional fluorescing organisms. Only a $2+$ fluorescence or higher reading was recorded as a positive result.

\section{STATISTICAL METHOD}

Statistical comparisons were made using the $\chi^{2}$ test with Yates's correction.

\section{Results}

IMMUNOGLOBULIN CONCENTRATIONS

The mean IgA and IgG concentrations in the supernate of the diluted cervical secretions were $11.4 \times 10^{-3} \mathrm{~g} / 1$ (standard deviation, SD $6.7 \times 10^{-3}$ ) and $30.5 \times 10^{-3} \mathrm{~g} / 1\left(\mathrm{SD} 20.6 \times 10^{-3}\right)$ respectively.

\section{INDIRECT IMMUNOFLUORESCENT-ANTIBODY TEST}

The results obtained when cervical secretions from patients in each of the three groups were examined for IgA and IgG antibodies reactive with $N$ gonorrhoeae are given in table $\mathrm{I}$.

\section{$\operatorname{Ig} A$}

IgA antibody was detected in $56(72 \%)$ of the 78 women with untreated gonorrhoea but in only 25 $(5 \%)$ of 490 non-infected women; the mean duration of infection in the 22 women in whom antibody was not detected was 16-6 days (range 4-48 days).

Antigonococcal IgA was found in cervical secretions from $24(22 \%)$ of 110 women who had been treated more than 28 days previously (mean interval between treatment and sampling, 422 days).

TABLE I Results of immunofluorescent-antibody test on cervical secretions from women with untreated and previously treated gonorrhoea and from non-infected patients

\begin{tabular}{|c|c|c|c|c|c|c|c|}
\hline \multirow[b]{3}{*}{ Antibody } & \multicolumn{7}{|l|}{ No of patients } \\
\hline & \multirow{2}{*}{$\begin{array}{l}\text { With untreated } \\
\text { gonorrhoea }\end{array}$} & \multicolumn{4}{|c|}{$\begin{array}{l}\text { With previously treated gonorrhoea (days between } \\
\text { treatment and sampling) }\end{array}$} & \multirow[b]{2}{*}{ Non-infected } & \multirow[b]{2}{*}{ Total } \\
\hline & & $\leqslant 7$ & $8-14$ & $15-28$ & $\geqslant 29$ & & \\
\hline $\begin{array}{l}\text { IgA only } \\
\text { IgG only } \\
\text { IgA and IgG } \\
\text { None }\end{array}$ & $\begin{array}{r}8 \\
7 \\
48 \\
15\end{array}$ & $\begin{array}{r}3 \\
0 \\
10 \\
1\end{array}$ & $\begin{array}{r}5 \\
12 \\
6 \\
9\end{array}$ & $\begin{array}{r}1 \\
6 \\
4 \\
11\end{array}$ & $\begin{array}{r}5 \\
16 \\
19 \\
70\end{array}$ & $\begin{array}{r}9 \\
73 \\
16 \\
392\end{array}$ & $\begin{array}{r}31 \\
114 \\
103 \\
498\end{array}$ \\
\hline Total & 78 & 14 & 32 & 22 & 110 & 490 & 746 \\
\hline
\end{tabular}

TABLE II Results of immunofluorescent-antibody test to detect antigonococcal IgA in cervical secretions from 78 women with untreated gonorrhoea compared with those of Gram-stain microscopy and culture

\begin{tabular}{lllll}
\hline & \multicolumn{2}{l}{ Positive results to direct microscopy and culture } \\
\cline { 2 - 5 } Fluorescent-antibody test & Gram-stain only & Culture only & Gram-stain and culture \\
\hline Antigonococcal IgA detected & 1 & 16 & 39 \\
Antigonococcal IgA not detected & 0 & 4 & 56 \\
Total & 1 & 20 & 57 & 78 \\
\hline
\end{tabular}




\section{IgG}

IgG antibody reactive with $N$ gonorrhoeae was demonstrated in the cervical secretions of $55(71 \%)$ of 78 women with untreated gonorrhoea and in 89 $(18 \%)$ of 490 non-infected patients. This antibody was found in the secretions of $19(17 \%)$ of the 110 women who had been treated for gonorrhoea at least 29 days previously.

\section{COMPARISON WITH GRAM-STAIN MICROSCOPY}

In relation to the results of culture, the sensitivity $(72 \%)$ of the fluorescent-antibody test with antiserum against $\operatorname{IgA}$ was almost identical to that of Gram-stain microscopy (74\%) (table II).

\section{ORAL CONTRACEPTIVES AND THE}

\section{FLUORESCENT-ANTIBODY TEST}

Data on the method of contraception, if any, were available for 60 women with gonorrhoea. Table III shows the results of the fluorescent-antibody test with IgA antiserum in relation to the contraceptive method used. Antigonococcal IgA was detected in 22 $(73 \%)$ of 30 women who used an oral contraceptive preparation but in only $12(40 \%)$ of 30 patients who used some other form of contraception or none. This difference in antibody detection is statistically significant $\left(\chi_{1}^{2}=5 \cdot 50 ; \mathrm{P}<0 \cdot 02\right)$.

TABLE III Influence of methods of contraception on the detection of antigonococcal $\mathrm{IgA}$ in cervical secretions from women with gonorrhoea

\begin{tabular}{llcl}
\hline & \multicolumn{2}{l}{ Results of fluorescent-antibody test } \\
\cline { 2 - 3 } Type of contraception & IgA present & IgA absent & Total \\
\hline Oral & 22 & 8 & 30 \\
IUD or none & 12 & 18 & 30 \\
Total & 34 & 26 & 60 \\
\hline
\end{tabular}

IUD $=$ intrauterine device

\section{Discussion}

In a previous study, ${ }^{7}$ IgA reactive with $N$ gonorrhoeae was demonstrated in the cervical secretions (obtained by aspiration) of $71(95 \%)$ of 75 women with untreated gonorrhoea. The rate of detection of antibody (72\%) was significantly lower in the present series and probably reflects the different sampling method; the mean IgA concentration in the secretions eluted from the swabs was $11.4 \times 10^{-3} \mathrm{~g} / \mathrm{l}$ compared with $24.0 \times 10^{-3} \mathrm{~g} / \mathrm{l}$ in secretions obtained by aspiration. ${ }^{7}$ The collection of secretions by the latter method is however cumbersome and not suitable for routine use in a busy clinic.
The sensitivities of the immunofluorescentantibody test with $\operatorname{IgA}$ antiserum and of Gram-stain microscopy were almost identical (72 and $74 \%$ respectively) but the former test was expensive and time-consuming, and results were not available for at least one hour after collection of specimens. Similar difficulties were encountered with direct fluorescentantibody procedures. ${ }^{11}$

Although antigonococcal $\operatorname{IgA}$ was detected in secretions from $25(5 \%)$ of $\mathbf{4 9 0}$ women who had no microbiological evidence of gonococcal infection, it cannot be assumed that these patients had not recently been infected. In previous studies, ${ }^{712}$ IgA antibody was not detectable in the cervical secretions of women who had been treated more than 14 days previously. From the present study however, it is clear that this antibody can be detected in the secretions a month or even longer after satisfactory treatment. It is possible that some of these 25 women had been treated inadvertently before attending the clinic. As previously shown, ${ }^{7}$ a local antibody response may be detected in known contacts in whom repeated microbiological examination fails to show active gonococcal infection.

It was of interest that antigonococcal IgA was detected significantly more frequently in cervical fluid from women with gonorrhoea who used an oral contraceptive preparation. Chipperfield and Evans ${ }^{13}$ showed that the mean concentration of $\operatorname{IgA}$ in cervical mucus was significantly higher in women using a combined pill than in women with natural cycles.

The low sensitivity and specificity of the fluorescent-antibody test using IgG antiserum is clearly shown. IgG antibody is frequently detected in cervical secretions from patients with nongonococcal cervicitis and is probably the result of transudation of natural serum antibody through the inflamed mucus membrane.

As IgM antibody is detectable in the secretions of only about $40 \%$ of women with gonorrhoea, ${ }^{7}$ the fluorescent-antibody test with IgM antiserum was not performed.

We wish to thank the staff of the two clinics for their assistance in the collection of specimens.

This project was supported by a grant (reference number K/MRS/50/C182) from the Scottish Home and Health Department.

\section{References}

1. Koransky JR, Jacobs NF. Serologic testing for gonorrhea. Sex Transm Dis 1977; 4:27-31.

2. Kellogg DS, Balows A. Immune response to Neisseria gonorrhoeae. In: Rose NR, Friedman H, eds. Manual of Clinical Immunology. Washington DC: American Society for Microbiology, 1976:280-4. 
3. McMillan A, McNeillage G, Young H, Bain SR. Serum immunoglobulin response in uncomplicated gonorrhoea. $\mathrm{Br} J$ Vener Dis 1979; 55:5-9.

4. Wilkinson AE. Indirect fluorescent test for the detection of antigonococcal antibodies. Br J Vener Dis 1975;51:28-30.

5. Ison CA, Glynn AA. Classes of antibodies in acute gonorrhoea. Lancet 1979; i: 1165-8.

6. Kearns DH, O'Reilly RJ, Lee L, Welch BG. Secretory IgA antibodies in the urethral exudate of men with uncomplicated urethritis due to Neisseria gonorrhoeae. J Infect Dis 1973; 127:99-101.

7. McMillan A, McNeillage, G, Young H, Bain SSR. The secretory antibody response of the cervix uteri to infection with Neisseria gonorrhoeae. Br J Vener Dis 1979; 55:265-70.

8. Barlow D, Phillips I. Gonorrhoea in women. Diagnostic, clinical and laboratory aspects. Lancet 1978; i:761-4.
9. Samson RR, McClelland DBL, Shearman DJC. Studies on the quantitation of immunoglobulin in human intestinal secretions. Gut 1973; 14:616-26.

10. O'Reilly RJ, Welch BG, Kellogg DS. An indirect fluorescentantibody technique for study of uncomplicated gonorrhea. II Selection and characterization of the strain of Neisseria gonorrhoeae used as antigen. $J$ Infect Dis 1973; 127:77-83.

11. Lind I. Identification of Neisseria gonorrhoeae by means of fluorescent antibody technique. Acta Pathol Microbiol 1967; 70:613-29.

12. O'Reilly RJ, Lee L, Welch BG. Secretory IgA antibody responses to Neisseria gonorrhoeae in the genital secretions of infected females. J Infect Dis 1976; 133: 113-25.

13. Chipperfield EJ, Evans BA. Effect of local infection and oral contraception on immunoglobulin levels in cervical mucus. Infect Immun 1975; 11:215-21. 